\title{
Corporate Financial Performance and Tobin's Q in Dividend and Growth Investing
}

Hanna Mysaka and Ivan Derun

ABSTRACT

Investor attracting and keeping requires both successful management of a company's financial performance and an investor's behavior knowledge, as well as monitoring of stock market current trends. This paper contains the study results on the influence of public companies' financial performance on Tobin's q as a common measure of investment opportunity for dividend (income) investors and growth investors in conditions of competition and financing limitations. The goal of this article is to identify the financial performance indicators of public companies, influencing their Tobin's q, for dividend (income) investing and growth investing respectively. We determined that the proxies for the variables of the Tobin's q function should be different for different investment styles. For this reason, we composed two sets of financial ratios that reflect financial performance specifics of dividend (income) stock companies and growth stock companies for the quantitative assessment of these investor types' preferences. The analysis results led to the conclusion that a company can attract attention of dividend (income) investors by demonstrating higher levels of dividend payments. Whereas, growth investors are sensitive to the level of company's business activities, which is related to its revenue. Based on the results of this study, we believe that investment decisions' successfulness depends on the reliability of the issuer's financial statements. In our conclusions, we suggest that public companies' managers focus on the financial performance that best correlate with the preferences of certain type of investors, which is a promising way to attract and keep their investors.

KEY WORDS: Dividend (income) investors, financial performance, growth investors, Tobin's q.

JEL Classification: G32, M41, G11.

Taras Shevchenko National University of Kyiv, Faculty of Economics, 90A Vasylkivska Street, Kyiv, Ukraine, 03022. Scientific affiliation: accounting and corporate finance.

\section{Introduction}

Acceleration of capital growth rate is crucial for the successful implementation of a company development strategy, especially in the context of limited funding sources. Those companies, which not only satisfy investors' expectations, but also are able to foresee them, can successfully use all opportunities, offered by the stock market in this area. Despite of over 35-year conflict between the Shareholder Value

Correspondence concerning this article should be addressed to: Hanna Mysaka, Taras Shevchenko National University of Kyiv, Faculty of Economics, 90A Vasylkivska Street, Kyiv, Ukraine, 03022. E-mail: mysaka_g@knu.ua.
Theory and the Stakeholder Theory in corporate governance and the adaptation of the Enlightened Shareholder Value principles in the Companies Act (The Parliament of England, 2006), a director still (amongst other matters) needs to manage the company's financial performance. In this connection, to make better economic decisions all stakeholders use financial statement analysis as an assessment tool to measure effectiveness of corporate performance management. 
Value-based management ensures increased earnings with the same cost of assets. Thereby, additional investment in a well-managed company would be more preferable because the generated profits would exceed the value of that company's assets. A financial market-based measure of a company's performance is the Q-ratio (or Tobin's q) which has been a driving factor behind investment decisions on the world stock market for almost fifty years since its introduction in 1969. Investment decisions to sell, buy, or hold shares are the result of the comparison of listed company's evaluation, subjectively formed by an investor, to this company's market capitalization as the value, obtained by multiplying its share price by total number of its shares outstanding on the stock market.

The Tobin's q adaptation for company level of analysis is calculated as a ratio (q) of the market value of company's assets to the replacement costs of those assets (Sharma et al., 2013). As the replacement values of a company's assets are difficult to estimate, there is an approximate Tobin's q based on the fundamental accounting equation (Assets $=$ Equity + Liability). For that reason in common financial practice, Tobin's $\mathrm{q}$ is calculated by comparing the market value of a company's equity (or company's market capitalization) and liabilities with their corresponding book values (Chung \& Pruitt, 1994). Since the revised in March 2018 Conceptual Framework for Financial Reporting widely advocates current value measurement base for the elements of financial statements, next assumption about equivalence of the liabilities' book value and their market value has a strong background and makes financial statements the main data source for Tobin's q calculation.

If Tobin's q (representing equilibrium) is greater than 1 , this indicates that the company requires a larger capital for the future period, and receives increased investors' attention. Conversely, a low Q-ratio (between 0 and 1) implies that the stock is undervalued and the issuer's assets would be more profitable to sell out separately. Therefore, it is crucial for an investor to identify a company's fundamental parameters that have the most influence on its intrinsic value that will allow the investor to categorize its stock correctly. For a comprehensive estimation of a company's fundamental value investors usually use a combination of several business valuation methods under the three main approaches:

- the cost approach, that focuses on a fair value of the company's net assets;

- the market approach, that uses transactional data about similar businesses' worth;

- the income approach, which estimates anticipated economic benefits from the company.

Investor attracting and keeping is the essential issue for publicly traded companies' managers. This problem is important in both scientific and practical terms, especially under the contemporary conditions of stock market volatility and limited funding sources. Solution to the problem requires both successful management of financial performance and investor behavior knowledge, as well as monitoring of stock market current trends.

A company's managers can raise the capital in the stock market by influencing its Tobin's q, which significantly depends on not only the company's current performance, but also future expected benefits from installed capital. Therefore, there is a practical need to measure a company's internally generated goodwill, which does not appear on the balance sheet but contributes an advantage with respect to other companies operating in the industry, and stock traders' assumptions about company's future performance, which may or may not be based on company's revenue and earnings. Since both a company's market capitalization and its assets book value have significant impact on Tobin's q, it can be represented as the function of dependence on three independent variables:

$y=f\left(z_{1}, z_{2}, z_{3}\right)$,

Where $z_{1}$ - net assets that would remain if the company was sold or liquidated at fair value; $z_{2}-$ internally generated goodwill as the value of unregistered intangible assets of the company, which create its additional competitive advantage; $z_{3}-\mathrm{fu}$ ture market expectations about earnings from the company growth and expansion updated by rational investors.

The last independent variable of the function (1) 
often causes significant changes in companies' market capitalization over short periods. The irrational behavior of real market participants, as well as their different access to information, has a destructive effect on stock market efficiency. Thus, risk tolerance and profitability expectations are subjective for every single investor. However, all investors usually classify stocks into one of three categories: value, growth (Fama \& French, 1998; Barberis \& Shleifer, 2003) and dividend (income), which Clemens (2013) considers as a subset of the value stocks.

Typically, objects of dividend (income) investing are stocks of mature companies, which moved past their initial growth stage and have to sustain high rate of capital appreciation by paying out retained earnings as dividends. They also have already had a certain size of assets and stable reputation gained, among other things, by way of mergers and acquisitions. Growth investors look for emerging companies, whose intrinsic value and earnings (or revenues) are expected to grow at an above-average rate, and this growth potential will transfer into capital appreciation during long- or short-term periods. Such companies tend to be in rapidly growing industries and prefer not to pay dividends, because they want to reinvest money maximally - through expansion, share repurchases, debt reduction, etc.

From this, it can be concluded that if a company identifies the target group of investors correctly and takes into account their expectations maximally, the market value of its stock will significantly raise because of increased investors' interest. Despite different aims and expectations, all types of investors use Tobin's q as a base for investment decisions making. At the same time, they analyze companies' financial statements as the most common and reliable source of information about a company's financial performance for its stocks' evaluating.

The potential investors' preliminary separation according to investment style will improve a publicly traded company's investor profiling management, based on the structuring of Tobin's q. Since company's key characteristics vary on the different phases of its business lifecycle, then applying of different criteria and financial ratios is crucial for efficiency of all investment strategies spectrum. Our goal is to identify the financial performance indica- tors of the publicly traded companies, influencing their Tobin's q, for attracting and keeping dividend (income) investors and growth investors respectively.

\section{Literature Review}

For a timely receipt of sufficient funding, a company should take into account many factors that determine investment style. Among these factors, macroeconomic and market trends (Hall, 1994; Lazonick \& O’Sullivan, 2000; Clarke, 2014; Alstadsæter et al., 2017), individual parameters of the company's functioning and its performance (Fama \& French, 1992; Piotroski, 2000; Chan \& Lakonishok, 2004; Clemens, 2013; Betermier et al., 2017; Penman \& Reggiani, 2018), as well as an investor's behavior (Fernández, 2007; Asker et al., 2015; Cronqvist et al., 2015), occupy an important place.

The company's financing strategy depends on the structural changes in the world economy and local trends in financial systems (such as interest rates and tax policy). Thus, the US market for corporate control had a serious negative impact on companies' long-term investment in nontechnology-intensive industries in the 1980s (Hall, 1994). Three waves of innovation not only have stimulated economic growth but also transformed the doctrine of maximizing shareholder value as a principle of corporate governance. Booms in the US stock market and the US economy in the 1970-90s have encouraged the significant changes of the US corporate strategy from an orientation towards retention of corporate earnings and reinvestment in corporate growth to one of distribution of corporate earnings to shareholders (Lazonick \& O'Sullivan, 2000). The structural transformation of finance resulted in a focus switch: non-financial sectors of the economy were displaced as the source of profitable activity. At the same time the role of financial metrics of a company's performance was increased in both financial and non-financial sectors of the economy. Still the existing investment relationships, and corporate purpose and objectives keep the agency theory and maximizing shareholder value in place as central impulses of the corporate economy (Clarke, 2014). According to study results provided by Alstadsæter et al. (2017) dividend tax policy as another driver of investment decisions affects the 
allocation of corporate investment. They found that the dividend tax cut leads to higher dividend payout by cash-rich companies and an investment increasing in cash-poor firms due to growth of external equity financing.

Due to results of Fama and French (1992) the ratio of book value to market value of equity (BV/MV) and company size as scaled versions of a firm's stock price became the basis for portfolio formation and performance evaluation by investors with different portfolio strategies. Some researchers (Chan \& Lakonishok, 2004; Penman \& Reggiani, 2018) have used BV/MV and the ratio of earnings to price (E/P) as indicators of a portfolio's orientation toward either growth or value. Penman and Reggiani (2018) have suggested that value investors should consider a high $\mathrm{BV} / \mathrm{MV}$ (with given $\mathrm{E} / \mathrm{P}$ ) as an indicator of higher expected earnings growth but that growth is risky. Their findings contrast with the standard convention that considers a low B/P for growth investing with lower risk. Simultaneously, Chan and Lakonishok (2004) have noted that the ratio of dividends to price $(\mathrm{D} / \mathrm{P})$ and the ratio of cash flow to price $(\mathrm{CF} / \mathrm{P})$ might also serve as the bases for investment strategies. Clemens (2013) empirically researched the portfolios based on $\mathrm{D} / \mathrm{P}$ and reached the conclusion that over the long run dividend investing has outperformed the market, and at the same time exhibited lower risk than the market. Thus, dividend investing has the same characteristics as value investing and low-volatility investing. Betermier et al. (2017) have revealed that growth investing is strongly linked to aggregate income risk and human capital. They have suggested that growth investors typically interest in emerging companies' stock, while value investors typically invest in the businesses in maturity stage.

For corporate financing strategy success, there is the urgent need to learn investors' behavior and promptings in the context of the limited funding sources. There are some theories, based on psychological or sociological behaviors, which suggest that stock price formation rather depends on the states of euphoria or pessimism predominating among stock market traders (Fernández, 2007). Asker et al. (2015) compared the investment behavior of public and private firms in the US, a country with well-developed financial markets and strong investor protection. They have determined that public firms invest substantially less and are less responsive to changes in investment opportunities, especially in industries in which stock prices are the most sensitive to earnings news. Authors believe this is a consequence of short-termist decisions of public firms' management, made under the pressure of investors' expectations. Cronqvist et al. (2015) revealed that investment style depends on an investor's hedging demands as well as behavioral biases. In addition, the authors found out that an investor's style has biological basis and investors with negative life experiences eventually prefer value stocks.

The study of an investor's behavior is always carried out in conjunction with the assessment of their expectations. Tobin (1969) introduced the Q ratio for estimation the fair value of stock market as whole. Its concept was based on the assumption that the long run equilibrium market value must be equal to the replacement value of its assets, given a $\mathrm{Q}$ value close to unity. The popularity of Tobin's q use for firm performance measurement has led to elaborating of its alternative estimators. Perfect and Wiles (1994) conducted an empirical study comparing five different estimators of Tobin's $q$ and concluded that each of them could be applied depending on the particular research conditions (for example, sample size, companies' size, research period, data sources, etc.). Since Tobin's q was adapted for company level, investors actively use it for predicting the firm's profitable investment (Lindenberg \& Ross, 1981; Chung \& Pruitt, 1994; Wilbur et al., 1997; Bayraktar, 2009; Sharma et al., 2013; Girod \& Whittington, 2017; Al-Malkawi \& Pillai, 2018). There are different indicators of investor expectation assessment, comparative analysis of which allow to make correct investment decision. If Tobin's q reflects the firm value by the market, then the ratio of price to earnings (P/E) determines whether stocks are correctly valued in relation to one another. Thus, Sum (2014) investigated the dynamic effect of Tobin's q on $\mathrm{P} / \mathrm{E}$ using a vector autoregressive analysis. Obtained results show that Tobin's q change causes $\mathrm{P} / \mathrm{E}$ to drop, but there is not a reverse causation from $\mathrm{P} / \mathrm{E}$ to Tobin's q change.

Neoclassical Q model of investment has also used as a base for modeling influence of firm's capital structure and financing costs on its optimal investment, 
performance, and risk management policies (Bolton et al., 2011; Vuong et al., 2017). Basing on the results of constructed model's testing, Bolton et al. (2011) came to conclusion that investment depends on the ratio of marginal $\mathrm{q}$ to the marginal value of liquidity (cash and credit line). Besides, the relation between investment and marginal $q$ changes with the marginal source of funding. Thus, marginal value of liquidity plays a central role in corporate decisions regarding investment, financing, and risk management. Vuong et al. (2017) have compared the association between firm's liabilities and financial performance in different industrial sectors of the UK to examine the impact of the financial crisis in 2008 on capital structure and financial results of listed companies on London Stock Exchange. Their outcomes indicate significant positive impact of both short-term and long-term liabilities on financial performance represented by Tobin's q.

Since Tobin's q is used as a common measure of a publicly traded company's performance, many studies were conducted to examine the relationship between Tobin's q and key performance indicators (Landsman \& Shapiro, 1995; Reddy et al., , 2010; Hejazi et al., 2016; Gharaibeh \& Quader, 2017; Palaniappan, 2017; Singh, Tabassum, Darwish, \& Batsakis, 2018). For instance, Reddy et al. (2010) revealed that firm performance measured by Tobin's q, the ratio of market value to book value of equity (MV/BV) and return on assets (ROA) of large listed companies in New Zealand have improved after implementation of principlebased corporate governance practices. Hejazi et al. (2016) determined that human capital and intellectual capital are positively related to performance (Tobin's q) of Iranian firms. Gharaibeh and Quader (2017) used Tobin's $q$ as measure of firm value and examined the influence a group of firm-specific factors on the value of companies from the dominant sectors of the Saudi Stock Exchange. Each selected variable has been assigned a financial performance indicator as a proxy. They found out that the main determinants of the firm value are market capitalization, growth opportunities, profitability, and solvency of the firm.

Palaniappan (2017) and Singh et al. (2018) have used Tobin's q for measuring of corporate performance of market-listed firms in the context of an emerging economy. They have examined the effect of corporate governance (as board size, CEO duality, etc.) and financial performance (as leverage, sales, etc.) on Tobin's q as a market-based firm performance measure. To test his hypotheses Palaniappan (2017) has used data from manufacturing firms listed in the National Stock Exchange of India Limited and concluded that among all selected financial indicators only firm size, measured as natural logarithm of sales deflated using WPI, had significant influence on Tobin's q. Meanwhile, Singh et al. (2018) failed to find positive link between Tobin's $\mathrm{q}$ and financial performance indicators of Pakistani listed firms.

Dushnitsky and Lenox (2006) have chosen Tobin's $\mathrm{q}$ as a measure of firm value rather than accountingbased measures (e.g., ROA). At the same time, the authors have used a number of financial performance indicators as control variables (e.g., capital costs, changes in sales, leverage, firm size, cash flow) of the corporate venture capital investment model. Analyzing a panel of the US public firms during 1990s, the researchers have concluded that growing firms with larger capital expenditures have higher Tobin's q.

There are many similar studies that devoted to the significant positive influence of R\&D costs (Connolly \& Hirschey, 2005; Srivastava \& Laplume, 2014; Wang, 2015; Kraft et al., 2018) and intangible resources, including unregistered ones, (Hall, 1993; Peters \& Taylor, 2017; Inamanamelluri et al., 2019) on the growth of the companies' market value. It is worth noting that they all used Tobin's $q$ as an indicator of changes in the market value of companies of different industries and sectors. On this background, the study of Rubera and Droge (2013) has some specific features. They set that the innovation may affect firm performance differently depending on branding strategy. Tobin's $\mathrm{q}$ was examined as dependent performance variable reflecting investor responses.

Our study differs from previous research. Firstly, we have determined that, for investor attracting and keeping, publicly traded companies' managers should differ the proxies for the variables of the Tobin's q function (1) according to investment styles. Secondly, we have composed the two sets of financial ratios that reflect financial performance specifics of dividend (income) stock companies and growth stock companies for the quantitative assessment of these investor types' preferences. These financial ratios were calculated using the financial statement data of the 
publicly traded companies. Tobin's q was calculated using information on the companies' market capitalization, book value of their assets and debts.

\section{Methodology}

Different items of financial statements are calculated on the historical cost or on the current value measurement bases. This objectively leads to a gap between the book value and market value of a company. Thus, the forecast result of changes in the stocks' market value, that investors anticipate, depends on which of these measurement bases the issuer uses to assess its financial statement items more often. Issuers need to increase the number and total value of financial statement items, which are assessed on the current value, for maximally approximating the company book value to its market value.

The US Generally Accepted Accounting Principles (US GAAP) and International Financial Reporting Standards / International Accounting Standards (IFRS/ IAS) are two most common systems of accounting and reporting standards in the world. At the same time, their requirements are not identical in cases when a company is required or permitted to measure its financial statements items at fair value. Fair value is one of the current value measurement bases, which has the broader application into US GAAP than IFRS/IAS (Herrmann et al., 2006). The United States Securities and Exchange Commission (SEC) adopted US GAAP as a set of accounting rules for the compiling of the publicly traded companies' financial statements. There is every reason to believe that for the companies listed on the US stock exchanges and reporting by US GAAP, the difference between their market value and book value is minimized due to frequent application of fair value as a measurement base for their financial statement items.

Investors' preferences and expectations determine their investment decisions about the companies' stocks and contribute to the fact that the stock exchanges acquire some specific features. Thus, the New York Stock Exchange (NYSE) and NASDAQ - two largest stock exchange operators by market capitalization of listed companies - are also known as the markets of stocks of different volatility. The NYSE has many of the big "blue chip" companies, which stocks are expected to be less volatile, so their investors are most conservative and dividend (income) oriented. Whereas, NASDAQ (as the first world market for high-tech companies) is place for trading stocks, which are considered more unstable but growth oriented.

For the purposes of this study the use of companies' financial statement data listed on the NYSE and NASDAQ provides an opportunity to differentiate investors and simultaneously ensures a unified approach to issuers' financial reporting based on US GAAP. Since investors use Tobin's $\mathrm{q}$ as a measure of investment opportunity, for attracting and keeping investors the publicly traded companies should manage their financial performance indicators, influencing a company's market capitalization and its assets book value as Tobin's q basic drivers. All things considered, we test three hypotheses:

H1: the issuers' financial performance indicators characterizing net assets have significant impact on both dividend (income) investors and growth investors;

$\mathrm{H} 2$ : the issuers' financial performance indicators as proxies for internally generated goodwill have a greater impact on dividend (income) investors, than growth investors;

H3: the issuers' financial performance indicators as proxies for market expectations have a greater impact on growth investors, than dividend (income) investors.

We have selected two sets of financial performance indicators as proxies for independent variables of the function (1) for two different investment styles. Then we have constructed two econometric models that determine the impact of these indicators on Tobin's $q$ as a base for investment decisions making by dividend (income) investors (2) and growth investors (3) based on panel data:

$y_{i t}=\alpha_{0}+\alpha_{1} \ln \left(x_{1 i t}\right)+\alpha_{2} \ln \left(x_{2 i t}\right)+\alpha_{3} \ln \left(x_{3 i t}\right)$

$+\alpha_{4} \ln \left(x_{4 i t}\right)+\varepsilon_{i t}$,

Where $y_{i t}$ - logarithmic Tobin's q ratio based on the natural logarithm; $x_{1 i t}$ - Asset to Equity ratio (Total Assets/Total Shareholder Equity); $x_{2 i t}$ Return on Intangible Assets (Net Income/(Average Net Intangible Assets+Average Goodwill); $x_{3 i t}$ Goodwill/(Net Intangible Assets+Goodwill) ratio; $x_{4 i t}$ - Dividend Payout ratio (Dividends/Net Income); $\alpha_{0}, \alpha_{1}, \alpha_{2}, \alpha_{3}, \alpha_{4}-$ parameters of econometric model (2); $\varepsilon_{i t}$ - stochastic remnants. 
$y_{i t}=\beta_{0}+\beta_{1} \ln \left(p_{1 i t}\right)+\beta_{2} \ln \left(p_{2 i t}\right)+\beta_{3} \ln \left(p_{3 i t}\right)$

$+\beta_{4} \ln \left(p_{4 i t}\right)+\varepsilon_{i t}$,

Where $p_{1 i t}-$ Debt to Equity ratio (Debt/Total Shareholder Equity); $p_{2 i t}$ - Return on Net Intangible Assets (Net Income/(Average Net Intangible Assets);

$p_{3 i t}{ }^{-} \mathrm{R} \& \mathrm{D}$ Costs/Operating Expenses ratio; $p_{4 i t}$ - Asset Turnover ratio (Revenue/Average Total Assets); $\beta_{0}, \beta_{1}, \beta_{2}, \beta_{3}, \beta_{4}$ - parameters of econometric model (3); $\varepsilon_{i t}$ - stochastic remnants.

All values of the independent and dependent variables were logarithmic for a normal distribution of the dependent variable (Tobin's q). In addition, this will make it possible to reduce distortion of the econometric models' parameters.

The choice of both models' variables was due to their relevance for assessment of the financial performance indicators influencing Tobin's $\mathrm{q}$ by dividend (income) investors (2) and growth investors (3). Since mature companies are less focused on expansion and at the same time they can more comfortably service debt, Asset to Equity ratio $\left(x_{1 i t}\right)$ provides the most appropriate characteristic for their net assets. As debt is paid out before equity in the event of a bankruptcy, fluctuations of this indicator allows dividend (income) investors to estimate a company's ability to raise capital and own unsystematic risk associated with a specific issuer simultaneously. As a measure of financial leverage Debt to Equity ratio $\left(p_{1 i t}\right)$ represents a significant aspect of financial strategy and capital structure that inherent to emerging companies in the fastestgrowing industries. Using this ratio, growth investors measure a company-issuer's aggressiveness in leveraging practices to increase its value and ability to avoid financial distress.

Regarding internally generated goodwill we proceeded under next assumptions:

- different factors form intangible nature of this phenomenon at various stages of company's life cycle;

- for public companies it is an excess of market capitalization over market value of net assets;

- some elements of internally generated goodwill match asset recognition criteria and are disclosed in the financial statements.
In the growth phase a company solidifies its market position by establishing own brand or product. Thereby, R\&D Costs/Operating Expenses ratio $\left(p_{3 i t}\right)$ shows how intensively a company finances into own innovations, whereas Return on Net Intangible Assets $\left(p_{2 i t}\right)$ indicates successfulness of their capitalized part as patents, know-how, etc. At maturity stage brand recognition gives the companies strong cash and market positions and they grow through acquisitions. Return on Intangible Assets $\left(x_{2 i t}\right)$ gives indirect indication of overall success of the company's innovations (as the book value of intangible assets) and goodwill. Goodwill/(Net Intangible Assets+Goodwill) ratio $\left(x_{3 i t}\right)$ points out to what part of the company's internally generated goodwill was formed by the efforts of absorbed businesses.

The investment style peculiarities also have significant impact on investors' criteria of estimation of future earnings expectations. Dividend Payout ratio $\left(x_{4 i t}\right)$ is the most relevant indicator for monitoring the risk profile of dividend (income) investors' earnings, because paying higher dividends is considered the best use of mature companies' profit. Since they have little room for additional growth, these companies drive up their stock price by sustaining a stable level of dividend payout. Emerging companies typically do not pay dividends but provide capital gains to their investors, if stock is sold price higher than the purchase price that was paid for it. Therefore, growth investors expect a stock price increase as a result of higher efficiency of issuer performance, namely forward earnings growth, and whether the asset value can double in five to seven years. Asset Turnover ratio $\left(p_{4 i t}\right)$ characterizes the level of company's business activities and indicates asset efficiency to generate revenue. Thus, it is determinant of the company's performance as a whole.

The testing of hypotheses was carried out in accordance with the World's Biggest Public Companies (Forbes magazine version) in 2013-2017. This ranking is based on a mix of four metrics: sales, profit, assets and market value. We re-sorted the annual lists by the company's market capitalization as the most significant indicator of the investors' interest. The basis of our sample was made up of the public 
companies that were represented in each annual ranking and ranked by the market capitalization at least 300th. Then we selected the public companies that are listed on the NYSE and NASDAQ. By sampling only the companies listed on the US stock exchanges their annual reports data are based on uniform requirements of the SEC, thus eliminating the chances of analytic data incomparability. All units of both samples should have made profit during the research period as a sign of their financial efficiency. For the companies listed on NASDAQ an additional requirement is the reflecting $R \& D$ Costs in the Income Statement (Statement of profit and loss and other comprehensive income for the period) as a separate item, which is an evidence of their level significance as intensity indicator of the company's search for innovations and growth. As a result, the data of 75 public companies listed on the NYSE for the model (2) and 34 companies listed on NASDAQ for the model (3) matched to the specified requirements for the selected samples. The financial portals MarketWatch and YChart were the sources of the financial statements and the company market capitalization.

Therefore, the formed sample consists of three dimensions, which are typical for panel data, namely: signs (independent variables) - the financial performance indicators, objects - the public companies, time - the reporting periods. The use of multi-factor regression with panel data provides leveling of individual heterogeneity of objects (public companies) and allows estimating the parameters of the proposed regression models more accurate.

Before applying these econometric models, all dynamical rows of independent variables were investigated for stationary using the Dickey-Fuller test.

\section{Empirical Data and Results}

According to the obtained results of the Dickey-Fuller test, all the dynamic series are stationary, which enables them to be taken into account in the proposed models for estimation the impact of finance performance on Tobin's q for dividend (income) investing and growth investing. This gives grounds for calculation the linear multiple regressions using the panel data of the financial performance indicators of 75 public companies listed on the NYSE (the model (2) parameter estimation which is presented in table 1 and table 2) and 34 companies listed on NASDAQ (the model (3) parameter estimation which is presented in table 3 and table 4 ).

The obtained results give grounds to assert that the model (2) is adequate to the Fischer criterion, but the variable $x_{3 i t}$ is not significant, since its Prob.(F-statistic) $>0.05$ (see table 1). Perhaps, dividend (income) investors do not pay much attention to the origin of additional competitive advantages of the issuer - selfcreated or purchased - accordingly it can be the reason of insignificance of this variable. Therefore, in order to adjust the model (2), insignificant factor was excluded. The results of the parameters of the adjusted model (2) are given in table 2 .

As a result of the adjustment, the model (2) retained the Fisher criterion adequacy, and all remained parameters are significant, since their Prob. (F-statistic) $<0.05$. At the same time, the exception of non-essential factor led to an increase in the density of the link between its components from $95.05 \%$ to $95.68 \%$, which indicates the significance of influence of the financial performance indicators on Tobin's $\mathrm{q}$ for dividend (income) investing (see table 2). Adjusted model (2) preserves all variables corresponding to the components of the original function (1). In addition, each of them has direct relationship with Tobin's q. Further analysis of the parameters of the model (2) allows us to draw the following conclusions:

- For dividend (income) investing Tobin's q undergoes the most significant changes under direct relationship of Return on Intangible Assets $\left(x_{2 i t}\right)$ and Dividend Payout ratio $\left(x_{4 i t}\right)$, which correspond respectively to internally generated goodwill and market expectations. It is testimony that dividend (income) investors are the most interested in return estimations of both issuer itself and own investments in it. At the same time, investors care about efficiency of the company's internally generated goodwill as a source of its competitive advantages and expected income even more than their own current profits. This can be interpreted as an attempt to assess the issuer's prospects to generate sufficient profit in the future periods for deciding to sell or hold the stocks.

- Relatively low impact of Asset to Equity ratio ( $x_{1 i t}$ ) indicates that dividend (income) investors are not particularly worried about the prospect of issuer bank- 
Table 1

Model (2) Parameter Estimation for Dividend (Income) Investing

\begin{tabular}{lcccc}
\hline Variable & Coefficient & Std. Error & t-Statistic & Prob. \\
\hline$x_{1 i t}$ & 0.067505 & 0.016324 & 4.135315 & 0.0000 \\
$x_{2 i t}$ & 0.133038 & 0.025178 & 5.283928 & 0.0000 \\
$x_{3 i t}$ & 0.045770 & 0.027642 & 1.655806 & 0.0991 \\
$x_{4 i t}$ & 0.116659 & 0.033836 & 3.447762 & 0.0007 \\
$\varepsilon_{i t}$ & 0.871787 & 0.069982 & 12.45722 & 0.0000 \\
& \multicolumn{2}{c}{ R-squared=0.950492; F-statistic=65.10875; Prob. $=0.000000$} & \\
\hline
\end{tabular}

Table 2

Adjusted Model (2) Parameter Estimation for Dividend (Income) Investing

\begin{tabular}{lcccc}
\hline Variable & Coefficient & Std. Error & t-Statistic & Prob. \\
\hline$x_{1 i t}$ & 0.067540 & 0.017399 & 3.881906 & 0.0001 \\
$x_{2 i t}$ & 0.133436 & 0.026864 & 4.967169 & 0.0000 \\
$x_{4 i t}$ & 0.120602 & 0.034028 & 3.544222 & 0.0005 \\
$\varepsilon_{i t}$ & 0.879189 & 0.053256 & 16.50886 & 0.0000 \\
& R-squared=0.956811; F-statistic $=76.17292 ;$ Prob. $=0.000000$ & \\
\hline
\end{tabular}

Table 3

Model (3) Parameter Estimation for Growth Investing

\begin{tabular}{lcccc}
\hline Variable & Coefficient & Std. Error & t-Statistic & Prob. \\
\hline$p_{1 i t}$ & 0.038426 & 0.016741 & 2.295303 & 0.0236 \\
$p_{2 i t}$ & 0.062323 & 0.022607 & 2.756781 & 0.0068 \\
$p_{3 i t}$ & 0.038822 & 0.099627 & 0.389677 & 0.6975 \\
$p_{4 i t}$ & 0.745937 & 0.075888 & 9.829500 & 0.0000 \\
$\varepsilon_{i t}$ & 1.658778 & 0.222517 & 7.454601 & 0.0000 \\
\end{tabular}

\section{Table 4}

Adjusted Model (3) Parameter Estimation for Growth Investing

\begin{tabular}{lcccc}
\hline Variable & Coefficient & Std. Error & t-Statistic & Prob. \\
\hline$p_{1 i t}$ & 0.039586 & 0.018790 & 2.106803 & 0.0374 \\
$p_{2 i t}$ & 0.052984 & 0.019242 & 2.753648 & 0.0069 \\
$p_{4 i t}$ & 0.732983 & 0.070187 & 10.44332 & 0.0000 \\
$\varepsilon_{i t}$ & 1.568772 & 0.068688 & 22.83905 & 0.0000 \\
& R-squared $=0.809568 ;$ F-statistic $=14.29955 ;$ Prob. $=0.000000$ & \\
\hline
\end{tabular}


ruptcy until the ratio reach unsustainable levels, which rarely happen to the mature companies.

The model (3) is adequate to the Fischer criterion, but the variable $p_{3 i t}$ is not significant, since its Prob. (F-statistic) $>0.05$ (see table 3 ). R\&D Costs/Operating Expenses ratio $\left(p_{3 i t}\right)$ is one of the company's innovation indicators. However, the high level of innovation costs does not only guarantee their commercial success in the future, but generally implies a decline in the company current profit-making. R\&D costs could be capitalized into intangible assets (as patents, know-how, intellectual property rights, trademarks, etc.) just in case of their successful carrying out. Obviously, growth investors believe that these costs are inevitable for the emerging company and are more interested in a high level of its financial performance, which could cover its $\mathrm{R} \& \mathrm{D}$ costs.

Therefore, in order to adjust the model (3), insignificant factor was excluded. The results of the parameters of the adjusted model (3) are given in table 4 .

As a result of the adjustment, the model (3) retained the Fisher criterion adequacy, and all remained parameters are significant, since their Prob.(F-statistic) $<0.05$. At the same time, the exception of non-essential factor led to a slight decrease in the density of the link between its components from $81.20 \%$ to $80.96 \%$, but it still indicates the significance of influence of the financial performance indicators on Tobin's q for growth investing (see table 4). Adjusted model (3) preserves all variables corresponding to the components of the original function (1). In addition, each of them has direct relationship with Tobin's q. Further analysis of the parameters of the model (3) allows us to draw the following conclusions:

- For growth investing Tobin's q undergoes the most significant changes under direct relationship of Asset Turnover ratio $\left(p_{4 i t}\right)$, which corresponds to market expectations. This can be explained by the fact that investors need a general idea of how efficiently the company is managed and what business prospects it has. In addition, the company's ability to generate revenue from its assets not only characterizes asset use efficiency in general but also is one of the business success factors.

- A much lower impact of Debt to Equity ratio $\left(p_{1 i t}\right)$ and Return on Net Intangible Assets $\left(p_{2 i t}\right)$ suggests that growth investors are more guided in their investment decision making by considerations of the issuer's growth and expansion than prudence about its current financial leverage and successfulness of its own innovation. In turn, this increases the riskiness of such investments.

Thus, $\mathrm{H} 1$ is rejected, and $\mathrm{H} 2$ and $\mathrm{H} 3$ are supported.

\section{Conclusions and Discussion}

This study results have implications for the World's Biggest Public Companies as it provides them with an opportunity to analyze the impact of their financial performance on Tobin's q as a measure of investment opportunity and aids the design of strategies for investor attracting and keeping. It will also help management of other public companies to be aware of the influence of their financial performance on Tobin's $\mathrm{q}$ for enhancing their corporate performance and increasing their market value.

This study makes a significant contribution to research into the impact of endogenous factors on Tobin's q of the World's Biggest Public Companies of Forbes magazine version. Since Tobin's $q$ is an indicator of the public company's efficiency, we consider it necessary to explore the significance of the influence of the public company's financial performance on Tobin's q as a common measure of investment opportunity for dividend (income) investors and growth investors in conditions of competition and financing limitations. Using regression analysis of financial performance of the two samples of the 75 companies that listed on the NYSE and the 34 companies that listed on NASDAQ over the years 2013-2017, the separate effects of the financial performance indicators on Tobin's $\mathrm{q}$ for dividend (income) investors and growth investors are investigated. The obtained results indicate that the public company's financial performance has significant impact on Tobin's $\mathrm{q}$ for attracting and keeping both dividend (income) investors and growth investors.

These findings are consistent with the empirical study results of the significance of the financial performance variables (such as Dividend Payout ratio, Fixed Assets Turnover, etc.) in the firm-level investment obtained by Bayraktar (2009). The researcher composes a set of financial variables to determining firms' financial position and uses Tobin's q to comparing with the mandated investment rate and the profitability shocks as the proxies for firms' invest- 
ment opportunities. The author points out that when Tobin's $q$ is the fundamental variable, the response of investment to changes in financial variables is relatively higher for financially constrained firms. At the same time, Landsman and Shapiro (1995) consider that financial statement data contain meaningful information about economic returns that investors find valuable. Their results confirmed the strong connection between the accounting return on investment as a measure of business performance and Tobin's $q$ as the market's prediction of the returns generated per dollar invested in corporate assets.

We also found evidence that the company can attract attention of dividend (income) investors by demonstrating consistently higher levels of dividend payments. In turn, growth investors are extremely sensitive to the level of company's business activities, which is directly related to the company's revenue. These important indicators of companies' financial performance are reflected in Statement of financial position at the end of the period (Balance Sheet) and Statement of profit and loss and other comprehensive income for the period (Income Statement). Thus, investment decisions' successfulness depends on the reliability and accuracy of the issuer's financial statements.

These additional findings are also concordant with the study results obtained by Piotroski (2000). He suggests that investors can use a simple accounting-based fundamental analysis strategy to select financially strong high book-to-market firms and to eliminate firms with poor future prospects from a generic high book-to-market portfolio. Based on his findings about a positive relationship between financial statement data and both future firm performance and subsequent quarterly earnings announcement, the author concludes that the market initially underreacts to the historical information. At the same he highlights that for value investing objectives achievement the benefits to financial statement analysis are concentrated in small and medium-sized firms, whereas we reveal the strong relation between large firms' financial performance and Tobin's $\mathrm{q}$ as a measure of investor expectations of a corporation's future economic returns for both dividend (income) investing and growth investing.

Thus, there is an objective need to modernize ex- isting accounting methods and develop new ones for correct evaluation and maximum disclosure of the elements of internally generated goodwill in the company's financial statements. Extension of application of fair value measurement for financial reporting items is another promising way to strengthen the analytical potential of financial statements. This will significantly increase the relevance of reporting data for investment decision-making because it will reduce divergence between the company's market value and its book value.

The findings of this study are limited to the companies' data that are under the SEC disclosure requirements. The companies, which listed on the other countries' stock exchanges, are under other regulatory rules that may result in the differences in disclosure and valuation of the financial statements' items. Therefore, it would be interesting to see if the results obtained hold in other developed countries. This limitation also applies to non-listed companies which market value should be calculated in other ways. Another issue for future research is a focus on the company's financial performance indicators that best correlate with the preferences of different types of investors.

\section{References}

Al-Malkawi, H. A. N., \& Pillai, R. (2018). Analyzing financial performance by integrating conventional governance mechanisms into the GCC Islamic banking framework. Managerial Finance, 44(5), 604-623. https://doi.org/10.1108/MF-05-20170200

Alstadsæter, A., Jacob, M., \& Michaely, R. (2017). Do dividend taxes affect corporate investment? Journal of Public Economics, 151, 74-83. https://doi. org/10.1016/j.jpubeco.2015.05.001

Asker, J., Farre-Mensa, J., \& Ljungqvist, A. (2015). Corporate investment and stock market listing: A puzzle? Review of Financial Studies, 28(2), 342390. https://doi.org/10.1093/rfs/hhu077

Barberis, N., \& Shleifer, A. (2003). Style investing. Journal of Financial Economics, 68(2), 161-199. https://doi.org/10.1016/S0304-405X(03)00064-3

Bayraktar, N. (2009). Investment, alternative measures of fundamentals and revenue indicators. International Journal of Revenue Management, 3(2), 148-178. https://doi.org/10.1504/ IJRM.2009.024162 
Betermier, S., Calvet, L. E., \& Sodini, P. (2017). Who are the value and growth investors? The Journal of Finance, 72(1), 5-46. https://doi.org/10.1111/ jofi. 12473

Bolton, P., Chen, H., \& Wang, N. (2011). A unified theory of Tobin's q, corporate investment, financing, and risk management. Journal of Finance, 66(5), 1545-1578. https://doi.org/10.1111/j.1540-6261.2011.01681.x

Chan, L. K., \& Lakonishok, J. (2004). Value and growth investing: Review and update. Financial Analysts Journal, 60(1), 71-86. https://doi.org/10.2469/faj. v60.n1.2593

Chung, K. H., \& Pruitt, S. W. (1994). A simple approximation of Tobin's q. Financial Management, 23(3), 70-74. https://doi.org/10.2307/3665623

Clarke, T. (2014). The impact of financialisation on international corporate governance: The role of agency theory and maximising shareholder value. Law and Financial Markets Review, 8(1), 39-51. https://doi. org/10.5235/17521440.8.1.39

Clemens, M. (2013). Dividend investing performance and explanations: A practitioner perspective. International Journal of Managerial Finance, 9(3), 185197. https://doi.org/10.1108/ijmf-06-2012-0065

Connolly, R. A., \& Hirschey, M. (2005). Firm size and the effect of R\&D on Tobin's q. R\&D Management, 35(2), 217-223. https://doi.org/10.1111/j.14679310.2005.00384.x

Cronqvist, H., Siegel, S., \& Yu, F. (2015). Value versus growth investing: Why do different investors have different styles? Journal of Financial Economics, 117(2), 333-349. https://doi.org/10.1016/j.jfineco.2015.04.006

Dushnitsky, G., \& Lenox, M. J. (2006). When does corporate venture capital investment create firm value? Journal of Business Venturing, 21(6), 753-772. https://doi.org/10.1016/j.jbusvent.2005.04.012

Fama, E. F., \& French, K. R. (1992). The cross-section of expected stock returns. The Journal of Finance, 47(2), 427-465. https://doi.org/10.1111/j.1540-6261.1992. tb04398.x

Fama, E. F., \& French, K. R. (1998). Value versus growth: The international evidence. The Journal of Finance, 53(6), 1975-1999. https://doi.org/10.1111/00221082.00080

Fernández, P. (2007). Company valuation methods. The most common errors in valuations. IESE Business School, 449, 1-27. https://doi.org/10.2139/ ssrn. 274973

Gharaibeh, A. M. O., \& Quader, A. A. A. A. (2017). Factors influencing firm value as measured by the Tobin's $Q$ : Empirical evidence from the Saudi Stock Exchange
(TADAWUL). International Journal of Applied Business and Economic Research, 15(6), 333-358.

Girod, S. J., \& Whittington, R. (2017). Reconfiguration, restructuring and firm performance: Dynamic capabilities and environmental dynamism. Strategic Management Journal, 38(5), 1121-1133. https://doi. org/10.1002/smj.2543

Hall, B. H. (1993). The value of intangible corporate assets: An empirical study of the components of Tobin's q. UC Berkeley, 93-207, 1-33. https://escholarship.org/content/qt44x548gq/qt44x548gq.pdf

Hall, B. H. (1994). Corporate restructuring and investment horizons in the United States, 1976-1987. Business History Review, 68(1), 110-143. https:// doi.org/10.2307/3117017

Hejazi, R., Ghanbari, M., \& Alipour, M. (2016). Intellectual, human and structural capital effects on firm performance as measured by Tobin's Q. Knowledge and Process Management, 23(4), 259-273. https:// doi.org/10.1002/kpm.1529

Herrmann, D., Saudagaran, S. M., \& Thomas, W. B. (2006). The quality of fair value measures for property, plant, and equipment. Accounting Forum, 30(1), 43-59. https://doi.org/10.1016/j.accfor.2005.09.001

Inamanamelluri, T., Hutchinson, R., \& Bernacchi, M. (2019). Intangible resource values and Tobin's q: Evidence from the Super Bowl. Journal of Accounting and Finance, 19(6), 104-118. https://doi. org/10.33423/jaf.v19i6.2317

Kraft, H., Schwartz, E., \& Weiss, F. (2018). Growth options and firm valuation. European Financial Management, 24(2), 209-238. https://doi.org/10.1111/ eufm. 12141

Landsman, W. R., \& Shapiro, A. C. (1995). Tobin's q and the relation between accounting ROI and economic return. Journal of Accounting, Auditing \& Finance, 10(1), 103-118. https://doi. org/10.1177/0148558X9501000108

Lazonick, W., \& O'Sullivan, M. (2000). Maximizing shareholder value: A new ideology for corporate governance. Economy and Society, 29(1), 13-35. https://doi.org/10.1080/030851400360541

Lindenberg, E. B., \& Ross, S. A. (1981). Tobin's q ratio and industrial organization. Journal of Business, $54(1), 1-32$.

Palaniappan, G. (2017). Determinants of corporate financial performance relating to board characteristics of corporate governance in Indian manufacturing industry. European Journal of Management and Business Economics, 26(1), 67-85. https://doi. org/10.1108/EJMBE-07-2017-005 
Penman, S., \& Reggiani, F. (2018). Fundamentals of value versus growth investing and an explanation for the value trap. Financial Analysts Journal, 74(4), 103119. https://doi.org/10.2469/faj.v74.n4.6

Perfect, S. B., \& Wiles, K. W. (1994). Alternative constructions of Tobin's q: An empirical comparison. Journal of Empirical Finance, 1(3-4), 313-341. https://doi. org/10.1016/0927-5398(94)90007-8

Peters, R. H., \& Taylor, L. A. (2017). Intangible capital and the investment-q relation. Journal of Financial Economics, 123(2), 251-272. https://doi.org/10.1016/j. jfineco.2016.03.011

Piotroski, J. D. (2000). Value investing: The use of historical financial statement information to separate winners from losers. Journal of Accounting Research, 38, 1-41. https://doi.org/10.2307/2672906

Reddy, K., Locke, S., \& Scrimgeour, F. (2010). The efficacy of principle-based corporate governance practices and firm financial performance. International Journal of Managerial Finance, 6(3), 190-219. https://doi. org/10.1108/17439131011056224

Rubera, G., \& Droge, C. (2013). Technology versus design innovation's effects on sales and Tobin's Q: The moderating role of branding strategy. Journal of Product Innovation Management, 30(3), 448-464. https://doi. org/10.1111/jpim.12012

Sharma, A, Branch, B. S., Chawla, C., \& Qiu, L. (2013). Explaining Market-to-Book: The relative impact of firm performance, growth, and risk. https://www. westga.edu/ bquest/2013/MarketToBook2013.pdf

Singh, S., Tabassum, N., Darwish, T. K., \& Batsakis, G. (2018). Corporate governance and Tobin's Q as a measure of organizational performance. British Journal of Management, 29(1), 171-190. https://doi. org/10.1111/1467-8551.12237

Srivastava, M. K., \& Laplume, A. O. (2014). Matching technology strategy with knowledge structure: Impact on firm's Tobin's $\mathrm{q}$ in the semiconductor industry. Journal of Engineering and Technology Management, 33, 93-112. https://doi.org/10.1016/j. jengtecman.2014.05.001

Sum, V. (2014). Dynamic effect of Tobin's Q on price-toearnings ratio. Managerial Finance, 40(6), 634-643. https://doi.org/10.1108/MF-07-2013-0193

The Parliament of England. (2006, November). Companies Act 2006. http://www.legislation.gov.uk/ukpga/2006/46/contents

Tobin, J. (1969). A general equilibrium approach to monetary theory. Journal of Money, Credit and Banking, 1(1), 15-29.

Vuong, N. B., Vu, T. T. Q., \& Mitra, P. (2017). Impact of capital structure on firm's financial performance:
Evidence from United Kingdom. Journal of Finance \& Economics Research, 2(1), 16-29. https://doi. org/10.20547/jfer1702102

Wang, M. C. (2015). Value relevance of Tobin's Q and corporate governance for the Taiwanese tourism industry. Journal of Business Ethics, 130(1), 223-230. https://doi.org/10.1007/s10551-014-2339-9

Wilbur, G., Lewellen, S. G., \& Badrinath, S. G. (1997). On the measurement of Tobin's q. Journal of Financial Economics, 44(1), 77-12. https://doi.org/10.1016/ S0304-405X(96)00013-X 